\title{
Quality Parameters and LAI of desi Wheat as Influenced by Various Combination of Nitrogen Fertilizer, Vermicompost and Azotobacter
}

\author{
Fazal Rabi, Meena Sewhag*, Shweta, Parveen Kumar, Neelam and Suresh Kumar \\ Department of Agronomy, CCS Haryana Agricultural University, Hisar, Haryana, India \\ *Corresponding author
}

\section{A B S T R A C T}

\section{Keywords}

Desi wheat,

Nitrogen, Quality,

Protein,

Vermicompost,

Azotobacter

Article Info

Accepted:

26 October 2019

Available Online:

10 November 2019
The present study entitled, Compensating nitrogen fertilizer requirement of desi wheat through Azotobacter and vermicompost was conducted during the rabi season of 2017-2018 at the Agronomy Research Farm of Chaudhary Charan Singh Haryana Agricultural University, Hisar to study the effect of Azotobacter and vermicompost on quality parameters of desi wheat. The soil of the experimental field is sandy loam in texture, slightly alkaline in reaction, low in organic carbon and nitrogen, medium in available phosphorus and potassium. The experiment was laid out in Randomized Block Design replicated thrice with ten treatments viz. $\mathrm{T}_{1}$ (Control), $\mathrm{T}_{2}$ (Vermicompost@6 tha $\left.{ }^{-1}\right), \mathrm{T}_{3}$ (Azotobacter+Vermicompost @6 tha $\left.{ }^{-1}\right), \mathrm{T}_{4}(30 \mathrm{~kg} \mathrm{~N}$ $\mathrm{ha}^{-1}+$ Vermicompost @ $\left.3 \mathrm{tha}^{-1}\right), \mathrm{T}_{5}\left(40 \mathrm{~kg} \mathrm{~N} \mathrm{ha}^{-1}+\right.$ Vermicompost @ $\left.2 \mathrm{tha}^{-1}\right), \mathrm{T}_{6}(50$ $\mathrm{kg} \mathrm{N} \mathrm{ha}{ }^{-1}+$ Vermicompost @ $\left.1 \mathrm{t} \mathrm{ha}^{-1}\right), \mathrm{T}_{7}\left(30 \mathrm{~kg} \mathrm{~N} \mathrm{ha}{ }^{-1}+\right.$ Azotobacter + Vermicompost@3 tha $\left.{ }^{-1}\right), \mathrm{T}_{8}\left(40 \mathrm{~kg} \mathrm{~N} \mathrm{ha}^{-1}+\right.$ Azotobacter + Vermicompost @ $2 \mathrm{t}$ $\left.\mathrm{ha}^{-1}\right), \mathrm{T}_{9}\left(50 \mathrm{~kg} \mathrm{~N} \mathrm{ha}^{-1}+\right.$ Azotobacter + Vermicompost @ $\left.1 \mathrm{t} \mathrm{ha}^{-1}\right)$ and $\mathrm{T}_{10}(60 \mathrm{~kg} \mathrm{~N}$ $\mathrm{ha}^{-1}$ ). Among various combinations of nitrogen fertilizer, vermicompost and Azotobacter treatments, highest LAI, protein content and protein yield of desi wheat was recorded in treatment receiving $100 \% \mathrm{RDN}\left(60 \mathrm{~kg} \mathrm{~N} \mathrm{ha}^{-1}\right)$. However, in terms of quality treatment $T_{9}$ and $T_{8}$ were at par with treatment $T_{10}$. But various treatments failed to produce any significant variation in harvest index of desi wheat.

\section{Introduction}

The positive effect of nitrogen on growth characters of wheat is proved beyond doubt (Sharma et al., 1980). Nitrogen, being an important constituent of protoplasts, amino acids and proteins, directly influences growth and development of plant through better utilization of photosynthates. Wheat (Triticum aestivum L.) is the second most important food crop and strategic cereal crop for the majority of the world's population. It is known as 'King of cereals' and India is the second largest producer of wheat in the world next to China. It is the most important staple food of about 2 billion people (around 36\% of the world population). Wheat grains are comparatively better source of protein consumed in India. About 10-12\% protein requirement of the country is met by 
consuming wheat. Maneuvering the application of different fertilizers could increase the productivity of the wheat crop and protein content. On account of ever increasing world energy crisis and spiraling prices of various chemical fertilizer, the use of organic manures as a renewable source of plant nutrients is gaining importance. In this endeavor proper combination of organic manure and inorganic fertilizer is important not only for increasing yield but also for sustaining soil health (Kumar et al., 2013).The use of organic manures largely excludes the use of synthetic fertilizers, pesticides, growth regulators and livestock feed additives, enriches the soil, encourages bio-diversity, reduce the toxic bodies, improves water quality, creates a safe environment for people and wild life, produces nutritious food of high quality, supply micronutrients in soil and maintains soil fertility and crop productivity (Sawrup, 2010). Keeping the above aspects in view, the present investigation "Compensating nitrogen fertilizer requirement of desi wheat by vermicompost and Azotobacter" has been planned with the objective to study the effect of vermicompost and Azotobacter on yield of desi wheat.

\section{Materials and Methods}

Field experiment was conducted during rabi 2017-2018 at the Agronomy Research Farm of Chaudhary Charan Singh Haryana Agricultural University, Hisar which is situated at latitude of $29^{\circ} 10^{\prime}$ North, longitude of $75^{\circ} 46^{\prime}$ East and elevation of $215.2 \mathrm{~m}$ above mean sea level in the semi-arid, subtropical climate zone of India. The experiment was laid out in Randomized Block on sandy loam (63.5\% sand, $17.3 \%$ silt and $19.2 \%$ clay) soil which is slightly alkaline in reaction, low in organic carbon and nitrogen, medium in available phosphorus and potassium. The treatment were comprised of ten treatments viz. $\mathrm{T}_{1}$ (Control), $\mathrm{T}_{2}$ (Vermicompost @6 $\mathrm{tha}^{-1}$ ), $\mathrm{T}_{3}$ (Azotobacter + Vermicompost @6 t $\left.\mathrm{ha}^{-1}\right), \mathrm{T}_{4}\left(30 \mathrm{~kg} \mathrm{~N} \mathrm{ha}^{-1}+\right.$ Vermicompost @ $3 \mathrm{t}$ $\left.\mathrm{ha}^{-1}\right), \mathrm{T}_{5}\left(40 \mathrm{~kg} \mathrm{~N} \mathrm{ha}^{-1}+\right.$ Vermicompost @ $2 \mathrm{t}$ $\left.\mathrm{ha}^{-1}\right), \mathrm{T}_{6}\left(50 \mathrm{~kg} \mathrm{~N} \mathrm{ha}^{-1}+\right.$ Vermicompost @ $1 \mathrm{t}$ $\left.\mathrm{ha}^{-1}\right), \mathrm{T}_{7}\left(30 \mathrm{~kg} \mathrm{~N} \mathrm{ha}{ }^{-1}+\right.$ Azotobacter + Vermicompost @ $\left.3 \mathrm{tha}^{-1}\right), \mathrm{T}_{8}\left(40 \mathrm{~kg} \mathrm{Nha}^{-1}+\right.$ Azotobacter + Vermicompost @ $\left.2 \mathrm{t} \mathrm{ha}^{-1}\right), \mathrm{T}_{9}$ $\left(50 \mathrm{~kg} \mathrm{~N} \mathrm{ha}^{-1}+\right.$ Azotobacter + Vermicompost @ $\left.1 \mathrm{tha}^{-1}\right)$ and $\mathrm{T}_{10}\left(60 \mathrm{~kg} \mathrm{~N} \mathrm{ha}^{-1}\right)$. Azotobacter was. Prior to sowing, the seed pertaining to inoculated plots was treated with Azotobacter culture obtained from Department of Microbiology, CCS Haryana Agricultural University, Hisar, as per treatment. The seed was wetted with sugar solution and $50 \mathrm{ml}$ of bio inoculants was used as per the recommendation. The treated seed was kept in shade for the completion of inoculation. Both treated and untreated seeds were sown as per the treatments. Sowing of Desi wheat C 306 was done on $10^{\text {th }}$ November 2017 at about 5.0 $\mathrm{cm}$ depth by drilling in rows using $120 \mathrm{~kg}$ seed ha ${ }^{-1}$ and spacing of $20 \mathrm{~cm}$ between rows. Pre-sown irrigation of $5 \mathrm{~cm}$ depth was applied on $3^{\text {th }}$ November 2017 . Three post sown irrigations were applied on 04.12.2017, 27.02.2018 and 13.03.2018. Harvesting was done with the help of sickles manually by cutting the plants from the net area of each plot separately on $11^{\text {th }}$ April 2018. Full dose of phosphorus $\left(62.5 \mathrm{~kg} \mathrm{P}_{2} \mathrm{O}_{5}\right.$ $\mathrm{ha}^{-1}$ ) and half nitrogen as per treatments were applied at the time of sowing and remaining half of the nitrogen was top dressed at 23 DAS.

Full dose of $\mathrm{P}$ and half dose of $\mathrm{N}$ as per treatments were applied to the field before sowing and rest of $\mathrm{N}$ was top dressed after first irrigation. Urea (46\%), Diammonium phosphate $\left(18 \% \quad \mathrm{~N}, \quad 46 \% \quad \mathrm{P}_{2} \mathrm{O}_{5}\right)$, and Azotobacter were used as source of $\mathrm{N}$ and $\mathrm{P}$. Five representative plants from each plot were selected randomly and tagged for recording the effect of different treatments on yield attributes. All yield attributes were recorded 
periodically on these randomly selected and tagged plants. Protein content of grain and straw was worked out by multiplying percent nitrogen in grain and straw respectively with a conversion factor of 6.25 . Harvest index (\%) was calculated for each plot by using following formula:

Harvest Index

$$
=\frac{\text { Grain yield }}{\text { Biological yield }} \times 100
$$

Leaves separated from the plants harvested for dry matter accumulation were used to measure leaf area with the help of LI 3000 area meter (LICOR LTD., Nabraska, USA).: The leaf area index was worked out with the help of following formula:

Leaf area index $=\frac{\text { Total leaf area }}{\text { Total land area }}$

\section{Results and Discussion}

The overall picture, based on one year data reflects the fact that among various combinations of nitrogen fertilizer, Azotobacter and vermicompost highest protein content was recorded in treatment $T_{10}$ which was significantly higher than treatment $\mathrm{T}_{1}, \mathrm{~T}_{2}, \mathrm{~T}_{3}$ and $\mathrm{T}_{4}$. Further protein content (\%) in treatment $T_{5}$ to $T_{10}$ was statistically at par with each other and significantly higher as compared to $\mathrm{T}_{1}, \mathrm{~T}_{2}, \mathrm{~T}_{3}$ and $\mathrm{T}_{4}$. Similar findings were also reported by Malik (2017) (Table 1). Similarly protein yield was highest in treatment $\mathrm{T}_{10}$ (368.4 $\mathrm{kg} \mathrm{ha} \mathrm{ha}^{-1}$, which was significantly higher than other treatments but statically at par with treatment $\mathrm{T}_{9}(361.4 \mathrm{~kg}$ $\left.\mathrm{ha}^{-1}\right)$. Lowest protein yield of desi wheat was obtained in treatment $\mathrm{T}_{1}\left(158.55 \mathrm{~kg} \mathrm{ha}^{-1}\right)$. The difference in protein yield in treatment $\mathrm{T}_{5}$ (305.0 $\mathrm{kg} \mathrm{ha}^{-1}$ ) and $\mathrm{T}_{7}\left(313.6 \mathrm{~kg} \mathrm{ha}^{-1}\right)$ were not significant. Similarly, the differences in protein yield of desi wheat in treatments $\mathrm{T}_{2}$ $\left(244.4 \mathrm{~kg} \mathrm{ha}^{-1}\right)$ and $\mathrm{T}_{3}\left(255.6 \mathrm{~kg} \mathrm{ha}^{-1}\right)$ were not significant. Optimum nitrogen levels were effective in producing better yield and quality of wheat grain. A proper supply of nitrogen through chemical fertilizer, Azotobacter and vermicompost helped to accumulate protein in grains and increase in grain weight. Similar results were recorded by Alghabari and AlSolaimani (2015). Malik (2017) also reported that barley grain protein content increased with increasing rates of $\mathrm{N}$ application and seed inoculation with Biomix produced highest protein content followed by seed inoculation with Azospirillum + PSB and Azotobacter + $P S B$ in barley at Hisar. These results were in unison with Mehrvarz and Chaichi (2008).Various combinations of nitrogen fertilizer and vermicompost failed to influence harvest index of desi wheat. The range of harvest index was between $26.3\left(\mathrm{~T}_{5}\right.$ and $\left.\mathrm{T}_{7}\right)$ to $29.2 \%\left(\mathrm{~T}_{2}\right)$. Leaf area index is an important parameter of photosynthesizing surface of plant and has pronounced effect on crop growth and yield. Leaf area ratio indicates the size of assimilatory surface area in relation to total dry matter accumulation. The increase in LAI of desi wheat was highest from 30 to 60 DAS (Table 2). Leaf area index was significantly higher with treatment $\mathrm{T}_{10}(100 \%$ RDN) at all the stages of crop growth and lowest value of leaf area index was obtained with treatment $T_{1}$ (0.62). However, the difference in leaf area index value between the treatments $T_{1}$ and $T_{2}$ at 30 DAS and between $\mathrm{T}_{9}$ and $\mathrm{T}_{10}$ at 60 DAS were at par with each. The findings confirmed with the results found by Rathore and Gautam (2003) and Kumar (2005).

On the basis of above findings, integrated application of $50 \mathrm{~kg} \mathrm{~N}^{-1}+$ Azotobacter + Vermicompost@1 t ha ${ }^{-1}$ or $40 \mathrm{~kg} \mathrm{~N} \mathrm{ha}{ }^{-1}+$ Azotobacter + vermicompost @ $2 \mathrm{t} \mathrm{ha}^{-1}$ or $100 \% \mathrm{RDN}$ in desi wheat to sandy loam, low in available $\mathrm{N}$, medium in available $\mathrm{P}$ soils can be practiced for higher profitability. 
Table.1 Effect of various combinations of nitrogen fertilizer, vermicompost and Azotobacter on protein content $(\%)$ and protein yield $\left(\mathrm{kg} \mathrm{ha}^{-1}\right)$ of desi wheat

\begin{tabular}{|c|c|c|c|}
\hline Treatments & $\begin{array}{c}\text { Protein } \\
\text { content } \\
(\%)\end{array}$ & $\begin{array}{c}\text { Protein } \\
\text { yield (kg } \\
\left.\text { ha }^{-1}\right)\end{array}$ & $\begin{array}{c}\text { Harvest } \\
\text { index } \\
(\%)\end{array}$ \\
\hline $\mathbf{T}_{1}:$ Control & 10.50 & 158.55 & 28.17 \\
\hline$T_{2}:$ Vermicompost @6t/ha & 11.75 & 244.40 & 29.20 \\
\hline $\mathbf{T}_{3}:$ Azotobacter + Vermicompost @ 6 t/ha & 12.00 & 255.60 & 28.80 \\
\hline $\mathrm{T}_{4}: 30 \mathrm{~kg} \mathrm{~N} / \mathrm{ha}+$ Vermicompost @ $3 \mathrm{t} / \mathrm{ha}$ & 12.25 & 278.08 & 26.70 \\
\hline$T_{5}: 40 \mathrm{~kg} \mathrm{~N} / \mathrm{ha}+$ Vermicompost @ 2 t/ha & 12.50 & 305.00 & 26.30 \\
\hline$T_{6}: 50 \mathrm{~kg} \mathrm{~N} / \mathrm{ha}+$ Vermicompost @ 1 t/ha & 12.63 & 321.94 & 26.50 \\
\hline $\begin{array}{l}\mathrm{T}_{7}: 30 \mathrm{~kg} \mathrm{~N} / \mathrm{ha}+\text { Azotobacter + Vermicompost @ } 3 \\
\text { t/ha }\end{array}$ & 12.75 & 313.65 & 26.30 \\
\hline $\begin{array}{l}\text { T}_{8}: 40 \mathrm{~kg} \mathrm{~N} / \mathrm{ha}+\text { Azotobacter + Vermicompost @ } 2 \\
\text { t/ha }\end{array}$ & 12.81 & 336.97 & 26.90 \\
\hline $\begin{array}{l}\text { T, }_{9}: 50 \mathrm{~kg} \mathrm{~N} / \mathrm{ha}+\text { Azotobacter + Vermicompost @ } 1 \\
\text { t/ha }\end{array}$ & 13.00 & 361.40 & 27.10 \\
\hline$T_{10}: \operatorname{RDN}\left(60 \mathrm{~kg} \mathrm{~N} \mathrm{ha}^{-1}\right)$ & 13.06 & 368.36 & 26.90 \\
\hline SEm \pm & 0.21 & 5.41 & 0.88 \\
\hline CD at $5 \%$ & 0.64 & 16.52 & N.S. \\
\hline
\end{tabular}

Table.2 Leaf Area Index of desi wheat as influenced by various combinations of nitrogen fertilizer, vermicompost and Azotobacter

\begin{tabular}{|c|c|c|c|c|}
\hline \multirow[t]{2}{*}{ Treatments } & \multicolumn{4}{|c|}{ Leaf Area Index } \\
\hline & $\begin{array}{c}30 \\
\text { DAS }\end{array}$ & 60 DAS & $\begin{array}{c}90 \\
\text { DAS }\end{array}$ & $\begin{array}{c}\text { At } \\
\text { Maturity }\end{array}$ \\
\hline $\mathbf{T}_{1}:$ Control & 0.62 & 2.30 & 3.65 & 0.81 \\
\hline$T_{2}:$ Vermicompost @ $6 \mathrm{t} / \mathrm{ha}$ & 0.65 & 2.41 & 5.12 & 0.85 \\
\hline $\mathrm{T}_{3}:$ Azotobacter + Vermicompost @6t/ha & 0.69 & 2.48 & 5.22 & 0.90 \\
\hline $\mathrm{T}_{4}: 30 \mathrm{~kg} \mathrm{~N} / \mathrm{ha}+$ Vermicompost @ $3 \mathrm{t} / \mathrm{ha}$ & 0.75 & 2.30 & 4.95 & 0.98 \\
\hline$T_{5}: 40 \mathrm{~kg} \mathrm{~N} / \mathrm{ha}+$ Vermicompost @ 2 t/ha & 0.79 & 2.41 & 5.12 & 1.03 \\
\hline $\mathrm{T}_{6}: 50 \mathrm{~kg} \mathrm{~N} / \mathrm{ha}+$ Vermicompost @ $1 \mathrm{t} / \mathrm{ha}$ & 0.80 & 2.48 & 5.22 & 1.04 \\
\hline $\mathrm{T}_{7}: 30 \mathrm{~kg} \mathbf{N} / \mathrm{ha}+$ Azotobacter + Vermicompost @ 3 t/ha & 0.85 & 2.30 & 5.06 & 1.11 \\
\hline $\mathrm{T}_{8}: 40 \mathrm{~kg} \mathrm{~N} / \mathrm{ha}+$ Azotobacter+ Vermicompost @ 2 t/ha & 0.80 & 2.41 & 5.12 & 1.04 \\
\hline$T_{9}: 50 \mathrm{~kg} \mathrm{~N} / \mathrm{ha}+$ Azotobacter+ Vermicompost @ 1 t/ha & 0.85 & 2.48 & 5.22 & 1.11 \\
\hline$T_{10}: \operatorname{RDN}\left(60 \mathrm{~kg} \mathrm{~N} \mathrm{ha}^{-1}\right)$ & 0.95 & 3.20 & 6.30 & 1.24 \\
\hline $\mathrm{SEm} \pm$ & 0.02 & 0.31 & 0.30 & 0.03 \\
\hline CD at $5 \%$ & 0.06 & 0.94 & 1.01 & 0.09 \\
\hline
\end{tabular}




\section{References}

Alghabari, F. and Al-Solaimani, S. G. (2015). Effect of sowing date and nitrogen fertilization on growth, yield and yield components of barley (Hordeum vulgare L.). International Journal of Innovation and Scientific Research, 18, 136-140.

Kumar, P. (2005). Effect of different nitrogen levels and biofertilizers strains on productivity and soil fertility in pearlmillet-wheat cropping system. $\mathrm{PhD}$ thesis, Chaudhary Charan Singh Haryana Agricultural University, Hisar, Haryana.

Kumari, Geeta, Thakur, S. K., Kumar, Navnit and Mishra, B. (2013) Long term effect of fertilizer, manure and lime on yield sustainability and soil or-ganic carbon status under maize (Zea mays)wheat (Triticum aestivum) cropping system in Alfisols. Indian Journal of Agronomy, 58(2):152-158.

Malik, P (2017) Response of barley to fertilizer levels and different combinations of biofertilizers. Ph. D. Thesis submitted to CCS HAU, Hisar.

Mehrvaraz, S., and Chaichi, M.R. (2008) Effect of phosphate solubilizing microorganisms and phosphorus chemical fertilizer on forage and grain quality of barely (Hordeum vulgare L.). American-Eurasian Journal of Agricultural and Environmental Sciences, 3 (6), 855-860.

Rathore, S.S. and Gautam, R.C. (2003). Response of direct seeded and transplanted pearlmillet (Pennisetum glaucum) to nitrogen, phosphorus and biofertilizers in intercropping system. Indian Journal of Agronomy, 48(3), $153-155$.

Swarup A. (2010) Integrated plant nutrient supply and management strategies for enhancing soil quality, input use efficiency and crop productivity. Journal of the Indian Society of Soil Science, 58 (1), 25-31.

\section{How to cite this article:}

Fazal Rabi, Meena Sewhag, Shweta, Parveen Kumar, Neelam and Suresh Kumar. 2019. Quality Parameters and LAI of desi Wheat as Influenced by Various Combination of Nitrogen Fertilizer, Vermicompost and Azotobacter. Int.J.Curr.Microbiol.App.Sci. 8(11): 2503-2507. doi: https://doi.org/10.20546/ijcmas.2019.811.288 